М.К. Глазатова

НИу ВШЭ, Москва

А.В. Данильцев

Основные тенденции в развитии мировой торговли и структурные особенности российского экспорта

Аннотация. Рассматриваются глобальные тенденции и структурные сдвиги в развитии международной торговли, имеющие фундаментальную основу, развитие которых будет продолжаться еще не одно десятилетие. Отмечается, что существенные преобразования особенно впечатляюще проявились в сфере коммуникаций, что, в свою очередь, повлияло на самый чувствительный в социальном плане сектор экономики - услуги. Анализируются причины кризисных явлений в многосторонней системе регулирования торговли, основанной на либерализации и типизации правил для традиционных форм торговли, а также нарастание протекционизма в условиях формирования торговых континентов - современных формах региональных соглашений. Затрагивается вопрос влияния развития регионализма на сужение пространства свободного рынка и обострение проблем взаимодействия экономических агентов. Рассматриваются риски, связанные с замедлением развития мировой торговли и применением торговых ограничений, а также с проблемами в сфере регулирования глобальной торговли. Особое внимание уделяется динамике изменений в структуре российского экспорта и отмечается явное несоответствие структуры российского экспорта потребностям рынка. Предполагается, что данный эффект может быть объяснен обострением конкуренции на мировом рынке, медленно восстанавливающейся после кризисных явлений мировой торговли, усиливающейся стагнацией внутреннего производства, нарастанием технологического отставания, а также накопившимися внутренними проблемами, которые снизили динамизм и возможности российской экономики. Обращается внимание на то, что среди ТОП-10 несырьевых российских экспортеров нет предприятий, деятельность которых связана со сферой цифровых технологий, в противоположность результатам мировых рейтингов, выдвигающих на первый план именно технологические компании.

Ключевые слова: международная торговля, протекиионизм, многосторонняя система регулирования торговли, экспорт.

Классификация JEL: F10, F13.

DOI: $10.31737 / 2221-2264-2020-45-1-8$

Многочисленные исследования, посвященные прогнозированию развития мировой экономики в стратегической перспективе (до 2030 г., или даже до 2050 г.), практически одинаково очерчивают основные глобальные изменения (PWC, 2017): цифровые технологии; уменьшение влияния развитых экономик по мере роста развивающихся стран, прежде всего стран Е7 (Бразилии, Индии, Индонезии, Китая, Мексики, России и Турции), а также еще более весомые успехи менее развитых стран (Нигерия, Колумбия); неравномерность воспроизводства, размещения, миграции и старения населения; рост нестабильности экономической политики ${ }^{1}$. Непредсказуемость экономической политики ведет к снижению инвестирования в основной капитал и спросу на инвестиционные товары, а цифровые технологии повлияли на трансформацию глобальных цепочек стоимости. Изменение политики регулирования в любом их звене ставит вопрос о стабильности сложившихся торговых потоков. В последние годы наблюдается рост различных торговых ограничений ${ }^{2}$, причем, как правило, преобладают нетарифные меры. Влияние тарифов на торговлю не является однозначным и зависит от характера товара и организации торговли, особенно

\footnotetext{
1 Рост индекса нестабильности экономической политики на $1 \%$ сопровождается снижением мировой торговли на 0,02 п.п. (Constantinescu, Mattoo, Ruta, 2019).

${ }^{2}$ При этом особую роль в данном случае играют взаимные ограничения в торговле между Китаем и США.
} 
в краткосрочном плане, однако может быть использовано как сильное и прямое ограничение, например практика введения тарифов в торговле между Китаем и США (World Bank Group, 2018), которую можно рассматривать как попытку США адаптироваться к нарастающему влиянию со стороны Китая в мировой торговле. Такие явления характерны для периодов смены лидеров, создают существенный ущерб и повышают риски для других участников рынка (Matoo, Staiger, 2019).

За последние почти четверть века структура мирового экспорта с точки зрения технологической сложности не изменилась. Волны кризисов 2008-2009 гг. и 2013-2014 гг. сначала снизили объемы торговли высокотехнологичной продукции и увеличили объемы торговли сырьевыми товарами, а затем показатели возвратились в исходное состояние конца 1990-х начала 2000-х годов (рис. 1).

Можно предположить, что достигнута стадия насыщения традиционного использования основных факторов производства. Технологии, в том числе гибридные, основанные на потреблении ископаемой или возобновляемой энергии, больше не позволяют в разы (как это было на протяжении всего XX в.) повышать әффективность производства. Дальнейшее повышение производительности труда на базе основных производственных мощностей, сформированных в последней четверти ХХ в., не столь эффективно. Основными факторами роста торговли товарами стал активный спрос на сырьевые и продоволь- ственные ресурсы в период высоких темпов развития мировой экономики до начала ее замедления после кризиса 2008-2009 гг., а в последующем - углубления внутриотраслевой специализации и обмене промежуточными товарами в рамках ГЦС. Развитие методов производства и масштабирование экономического обмена ресурсами и товарами подошло к переходу в следующую фазу развития на основе цифровых технологий. В ней «виртуальные и физические системы производства гибко взаимодействуют друг с другом на глобальном уровне, создавая новые операционные модели», в результате которых продукты «абсолютно настраиваются» под потребление (Schwab, 2016). Такой вектор выводит на первый план сектора экономики, связанные с предоставлением услуг (рис. 2).

Товары, прежде всего, готовые изделия, все еще продолжают оставаться лидером мировой торговли по объемам, но темпы расширения находятся в низкой и средней зонах. Торговля услугами уже в стоимостном выражении сопоставима с торговлей сырьем и топливом и продукцией машиностроения, но при этом существенно опережает последнюю по темпам развития и выходит на передовые позиции, особенно в сферах деловых услуг, компьютерных и информационных услуг. В определенном смысле услуги становятся настоящим хитом мировой торговли. Спрос все более кастомизируется и вовлекает в оборот товары, подстроенные под агрегированную потребность (например, «умный дом», здоровый



Рис. 1

Разница между среднегодовъми темпами прироста мирового экспорта различнъхх категорий товаров и мирового ВВП (n.n.) (правая осъ - темпъ прироста ВВП)

Источник: составлено по данным ЮНКТАД.
Среднегодовые темпы прироста мирового ВВП (правая шкала \%)

--- Трудоемкая и ресурсоемкая обработанная продукция

— Технически сложная продукция, которая не требует труда высокой квалификации

- - - Технически сложная продукция, которая требует труда средней квалификации

- Технически сложная продукция, которая требует труда высокой квалификации 

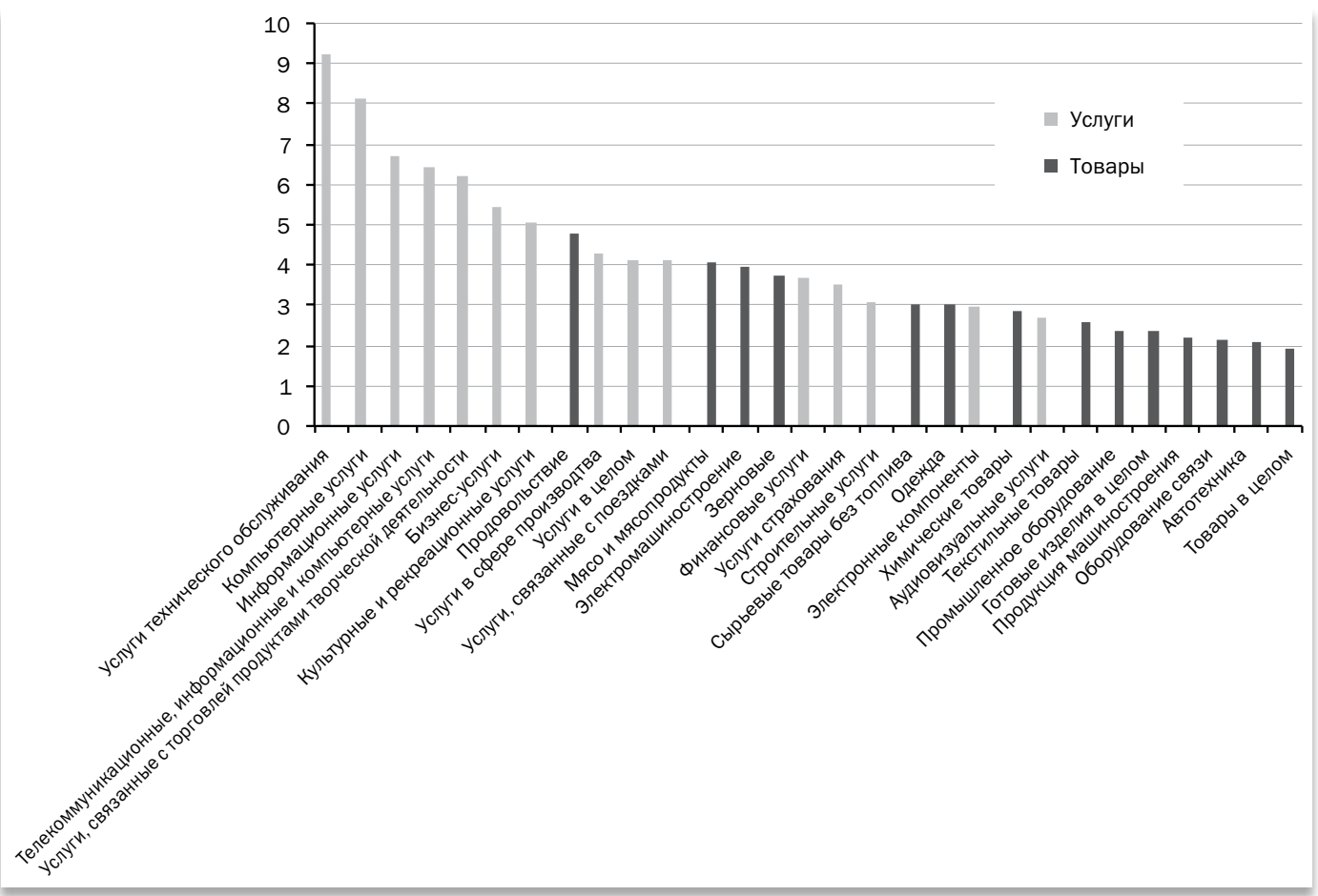

Pис. 2

Среднегодовые темпы прироста экспорта 29 наиболее динамичных секторов товаров и услуг в период 2006-2008 г2. - 2015-2017 г2., \%

Источники: составлено по данным ЮНКТАД, Всемирного банка.

образ жизни, «зеленые» технологии и т.п.), реализация которых сопряжена с предоставлением именно услуг (рис. 3).



Pис. 3

Позииионирование укрупненнъх отраслей в мировой торговле с учетом динамики экспорта и роли в мировой экономике (по горизонтали среднегодовые темпы прироста экспорта 20082017 ге.; по вертикали - средняя доля экспорта в мировом ВВП 2015-2017 г2.), \%

Источники: составлено по данным ЮНКТАД, Всемирного банка.
По совокупности показателей доли в мировой торговле и темпов расширения продуктовых отраслей и секторов услуг можно выделить следующие категории:

1) ориентированные на внутренний рынок, характеризуются невысоким удельным весом в мировой торговле и низкими темпами роста (металлообрабатывающее оборудование, уникальное промышленное оборудование, лесобумажные товары, офисное оборудование, топливо, электронное оборудование, услуги государственного управления);

2) динамично развивающиеся секторы услуг, связанные с цифровой и информационной экономикой, - наиболее перспективная часть международной торговли (компьютерные услуги, информационные услуги, услуги таежнического характера, услуги, связанные с торговлей продуктами творческой дея- 
тельности); эти секторы имеют невысокий удельный вес в мировой торговле, но характеризуются высокими темпами роста;

3) нацеленные на обеспечение текущих потребительских и инвестиционных потребностей - им свойственны невысокий удельный вес в мировой торговле и средние темпы роста (услуги в сфере промышленности, строительство, страховые и финансовые услуги, зерновые, әнергетическое и промышленное оборудование, оборудование связи, транспортное оборудование, текстиль, одежда, сырье для их производства);

4) производящие продукцию, используемую как компоненты и сырье, как правило, традиционного характера, обладающие высоким удельным весом и средними темпами расширения (электрооборудование, автотехника, нетопливное сырье, продовольствие, химические товары, разные готовые изделия, электронные компоненты). Исключение - сектор электронных компонентов, имеющий довольно высокий удельный вес при относительно невысоких темпах роста.

Еще одним существенным трендом, активно формирующимся в последние два десятилетия, является сокращение пространства сводного рынка, во многом обусловленное регионализацией, возникшей как противодействие глобальному либерализму, сократившему возможности проведения протекционистской политики на национальном уровне. Либерализация и унификация в применении инструментов регулирования проникла достаточно глубоко, уровень тарифной защиты у большинства стран не превышает 9,3\%, что, конечно, не предел, но дальнейшее снижение «в итоге приведет к вытеснению уже самого механизма защиты внутреннего рынка» (Глазатов, 2017). Аналогичная ситуация сложилась и в отношении нетарифных инструментов регулирования: в основе технических норм и правил используются, как правило, стандарты ИСО, в соглашениях ВТО - детализируются правила государственной поддержки и т.п. Однако пока применение нетарифных барьеров все еще остается существенным препятствием и излюбленной формой протекционизма. Обобщенный анализ показывает, что интенсивность применения нетарифных мер, и их влияние на развитие торговли даже возрастает (Симачев, Данильцев, Глазатова и др., 2018) (рис. 4).

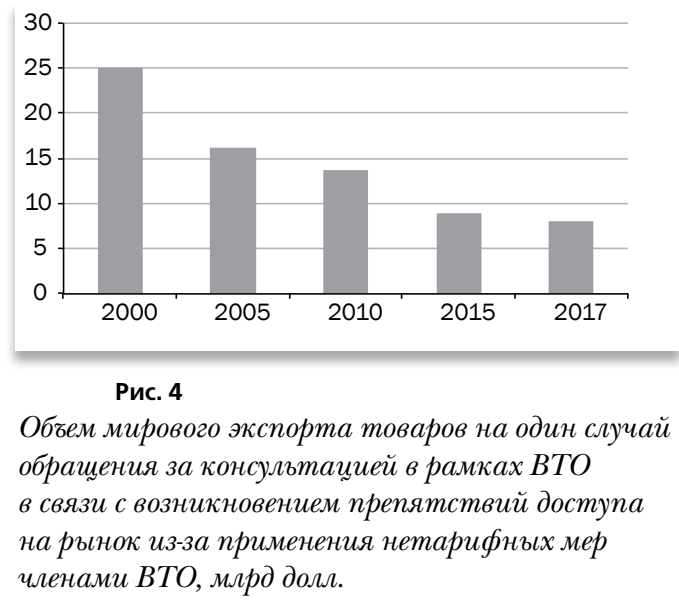

Источники: составлено по данным ВТО и ЮНКТАД.

Государства оказались в довольно сложной ситуации: с одной стороны, необходимо снижать барьеры торговли, а с другой стороны, достижение целей экономического роста также связано с развитием национальных производств. На стыке этих противонаправленных векторов стала формироваться новая конструкция взаимодействия - региональные соглашения стран, объединенных также на микроуровне предприятий глобальными цепочками добавленной стоимости (ГЦС) и уровнем применяемых технологий. Центр тяжести ограничивающих факторов перемещается на меры внутреннего регулирования и региональные договоренности, что позволяет странам-участницам проводить протекционистскую политику (рис. 5).

В свете вышесказанного очевиден кризис многосторонней системы регулирования торговли, основанной на либерализации, достигшей, в определенном смысле, предельных значений, и типизации правил для традиционных форм торговли, при том, что они әволюционно замещаются формами, основанными на цифро- 


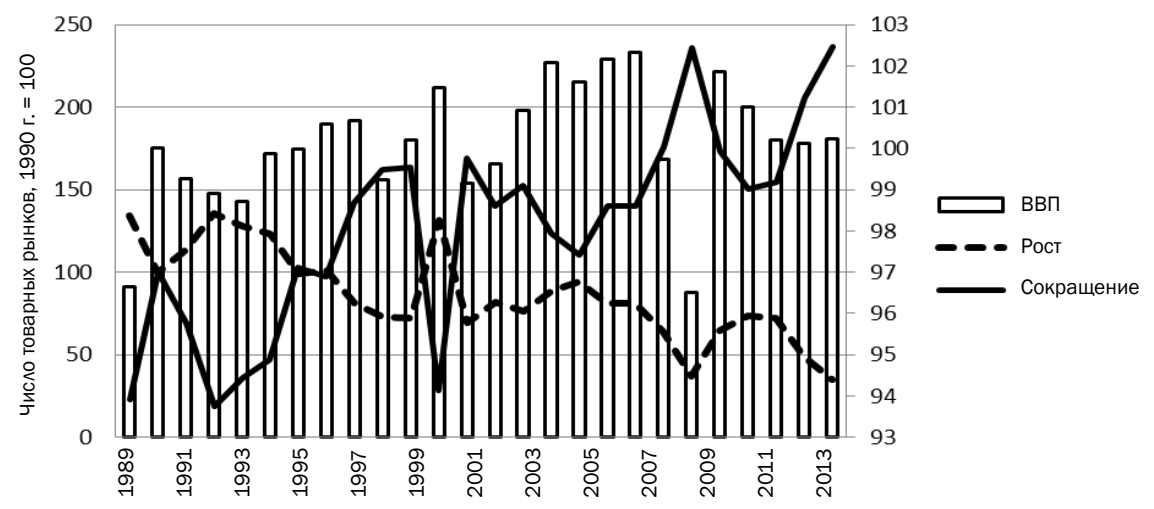

Рис. 5

Число товарных рынков, для которых число экспортеров увеличивалосъ (рост)/сокрашалосъ (сокр) по сравнению с предыдущим годом (1990 г. = 100, число рынков 5038) и темпь роста мирового ВВП, правая шкала в \% к предыдущему году

Источники: составлено по данным ЮНКТАД, Всемирного банка.

вых технологиях. Но и новый тип регионализма не является универсальным компромиссным средством, поскольку, в итоге, делит общий рынок на торговые континенты (табл. 1).
Таким образом, исходя из условий обострения проблем международной торговли, можно предложить двухступенчатый путь таргетирования современных рисков.

Таблица 1

Сравнительная таблица проблем и рисков многостороннего и регионального регулирования

\begin{tabular}{|c|c|c|}
\hline $\begin{array}{l}\text { Проблемы } \\
\text { и риски }\end{array}$ & Многостороннее регулирование & Региональное регулирование \\
\hline Успехи & $\begin{array}{l}\text { Соглашение по упрощению проце- } \\
\text { дур торговли. } \\
\text { Ограничения экспортных сельскохо- } \\
\text { зяйственных субсидий }\end{array}$ & $\begin{array}{l}\text { Рост числа локальных зон свободной } \\
\text { торговли. } \\
\text { Расширение сферы охвата региональных } \\
\text { торговых соглашений }\end{array}$ \\
\hline $\begin{array}{l}\text { Проблемы } \\
\text { и неудачи }\end{array}$ & $\begin{array}{l}\text { Отсутствие прогресса переговоров } \\
\text { Дохийского раунда. } \\
\text { Атаки со стороны США. } \\
\text { Торговые войны США представля- } \\
\text { ют опасность не только возвратом } \\
\text { торговых ограничений, но и попыт- } \\
\text { ками добиться либерализации под } \\
\text { интересы одного главного игрока }\end{array}$ & $\begin{array}{l}\text { Замедление создания новых ЗСТ, «спа- } \\
\text { гетти»3 РТС не охватили всего мира и не } \\
\text { стали вершиной либерализации. } \\
\text { Небольшое число РТС с глубокой интегра- } \\
\text { ционной повесткой (т.е. с либерализацией } \\
\text { движения всех факторов производства). } \\
\text { Неудачи крупных РТС (мега-РТС). } \\
\text { Проблемы ЕС (выход Великобритании из } \\
\text { состава ЕС) }\end{array}$ \\
\hline Риски & $\begin{array}{l}\text { Замедление процесса либерализа- } \\
\text { ции торговли. } \\
\text { Усиление протекционизма. } \\
\text { Дискриминация и фрагментация } \\
\text { глобального рынка }\end{array}$ & $\begin{array}{l}\text { Замедление процесса либерализации } \\
\text { торговли. } \\
\text { Рост протекционизма в новых областях. } \\
\text { Конкуренция между блоками }\end{array}$ \\
\hline
\end{tabular}

Источник: составлено авторами.

\footnotetext{
${ }^{3}$ Spaghetti bowl effect (эффект миски спагетти) состоит в увеличении числа соглашений о свободной торговле (ССТ), вытесняющих многосторонние переговоры Всемирной торговой организации в качестве альтернативного пути к глобализации (Bhagwati, 1995).
} 
1. Мировой уровень: 1) укрепление многосторонних принципов, что не допускает фрагментации мирового рынка; 2) расширение сферы многостороннего регулирования и сужение поля для становления новых форм протекционизма. Ключевые направления: инвестиции, цифровая экономика и услуги.

2. Региональный уровень: 1) приоритет созданию условий для движения факторов производства - инвестиций и обслуживающих их услуг; 2) открытое взаимодействие с третьими партнерами (привлечение ресурсов и участие в трансфере технологий); 3) развитие человеческого капитала, который является ключом к успеху в будущем мире креативных технологий.

В этот же период (последние 20 лет) в структуре российского экспорта не произошло существенных сдвигов в сторону обработанной продукции, за исключением некоторого увеличения доли продукции невысокого передела (промышленные полуфабрикаты) (рис. 6).

$\mathrm{C}$ точки зрения соотношения экспорта сырьевой и обработанной продукции структура и динамика экспорта РФ сходна с динамикой и структурой экспорта таких стран, как Норвегия, Чили, страны ОПЭК, Австралия и до некоторой степени Аргентина. Однако

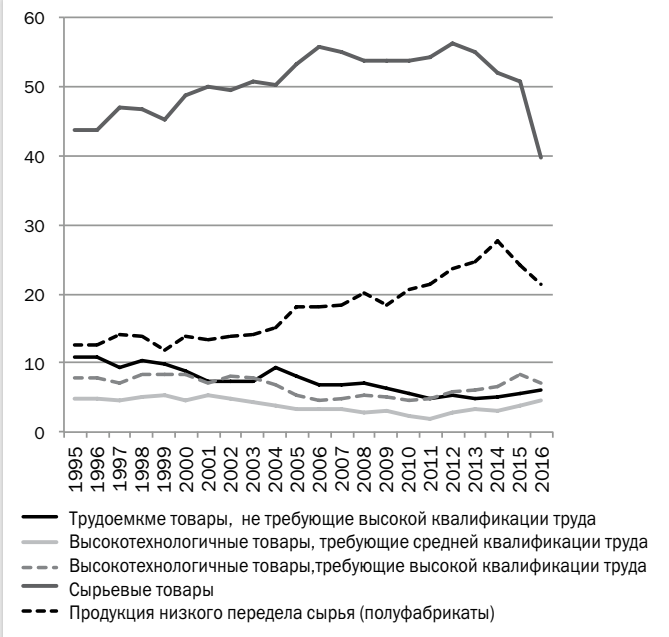

\section{Рис. 6}

Доля отдельнъх категорий товаров в экспорте РФ 1995-2017 г2., в \%

Источник: составлено по данным ЮНКТАД (см. https:// unctadstat.unctad.org/wds/TableViewer/tableView. aspx?ReportId=24739). перечисленные экономики существенно отличаются от российской экономики небольшим размером населения (в ОПЭК входят отдельные страны с большой численностью населения - Нигерия, Иран, Ирак, Венесуэла, однако в целом в данной группировке ключевую роль играют страны с небольшой численностью населения). Этот фактор существенно облегчает и расширяет возможности использования сырьевого әкспорта как основы для әкономического роста и технологического развития. Характер российской экономики - с большим населением, диверсифицированной структурой и высокой социальной нагрузкой - существенно затрудняет использование преимуществ сырьевого экспорта. Для других стран (Бразилия, Канада, ЮАР, США), также сырьевых экспортеров, характерна заметно более высокая доля обработанной продукции в экспорте (рис. 7).

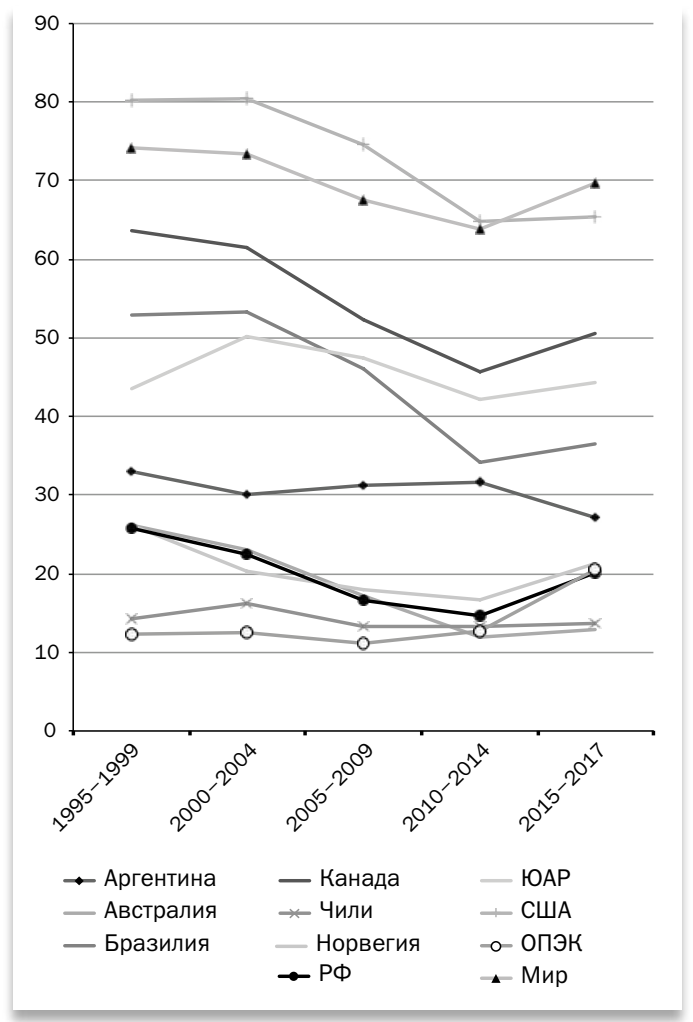

Рис. 7

Изменение доли обработанной продукиии в экспорте отдельных стран и ОПЭК, в \% по вертикали, по горизонтали - годы.

Источник: составлено по данным ЮНКТАД. 


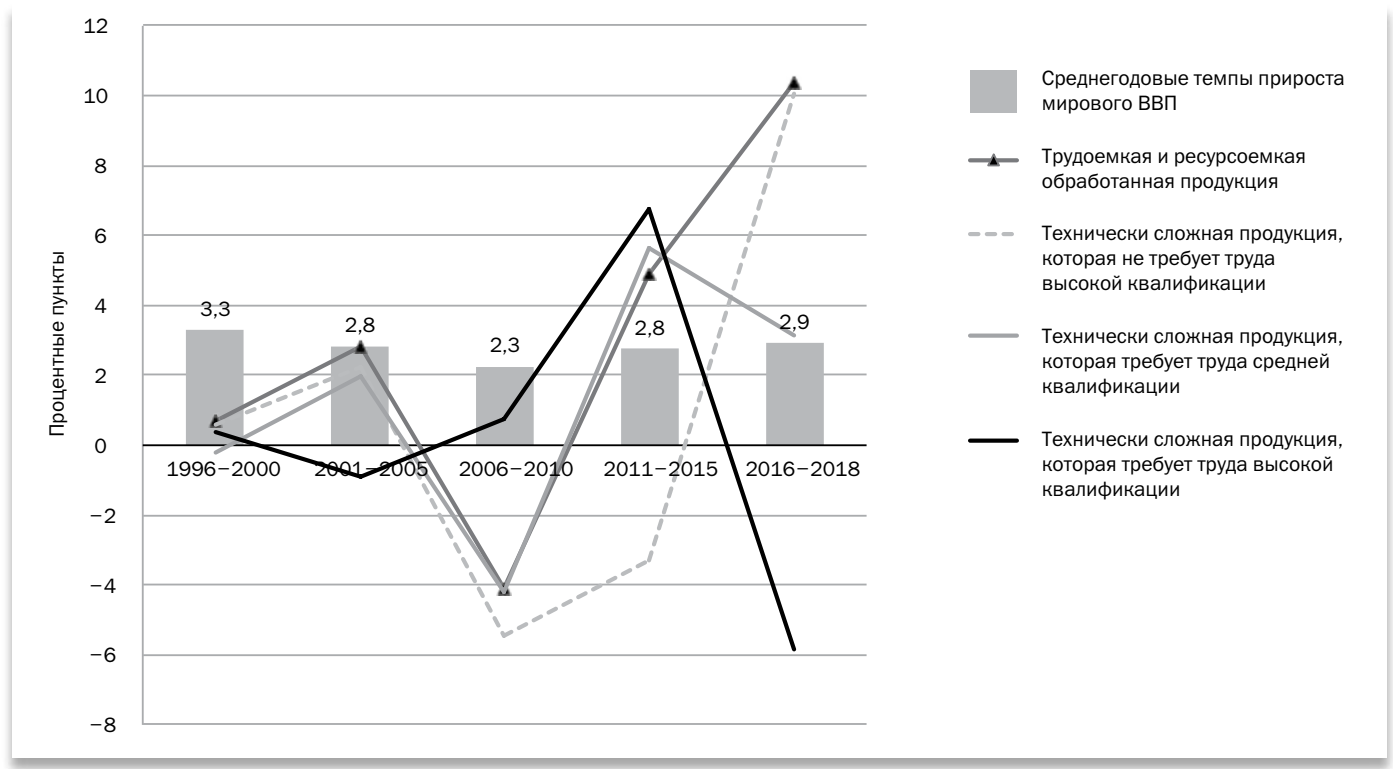

Pис. 8

Разнииа между среднегодовыми темпами прироста экспорта РФ и мирового экспорта различных категорий товаров, n.n., столбики - среднегодовые темпы прироста мирового ВВП, \%.

Источник: составлено по данным ЮНКТАД.

Динамика структуры российского экспорта в разрезе долей продукции, произведенной с использованием труда различного уровня квалификации, показывает, что в период 2011-2015 гг. темпы прироста экспорта высокотехнологичной продукции, требующей труда высокой квалификации, значительно упали и в 2016-2018 гг. оказались на 6 процентных пунктов ниже мировых (рис. 8).

Темпы роста доли продукции со средней квалификацией труда оставались выше, чем среднемировые, но имели тенденцию к снижению. А темпы роста продукции с использованием труда низкой квалификации после 2010 г. непрерывно росли относительно среднемирового показателя. Иными словами, восстановление российского экспорта после глобального кризиса 2008-2009 гг. происходило в основном на основе продукции с низкой квалификацией труда или ресурсоемкой, что показывает низкую конкурентоспособность российской высокотехнологичной продукции и ее вытеснение с мирового рынка.

Российская экономика благодаря своей тяжелой сырьевой структуре, оказалась не способной мобильно ориентироваться в новых экономических и технологических условиях. В ближайшее время не стоит ожидать улучшения внешнеэкономических условий для нашего развития. Не просто перемены, а глубокая трансформация должна произойти и в проведении государственной политики развития производств и отраслей, и в поведении самих экономических агентов, то есть на микроуровне - в деятельности предприятий, побуждая разворачивать высокотехнологичные производства. Анализ изменений в рейтинге самых крупных по уровню капитализации компаний показывает, что компании, которые основывают свой бизнес на цифровых технологиях, выдавливают с первых строчек ТНК из индустриального сектора экономики, и даже традиционных секторов услуг (табл. 2 и 3). Среди российских компаний нет ни одного предприятия, даже среди несырьевых экспортеров, сфера деятельности которых была бы связана с современными цифровыми технологиями. Нарастающий отрыв структуры крупного российского бизнеса от мировых тенденций еще больше свидетельствует о возрастании риска его опасного застревания на периферии мировой экономики. 
Таблица 2

Рейтинг капитализации крупнейших компаний мира, 2018 г.

\begin{tabular}{|c|c|c|c|c|c|}
\hline 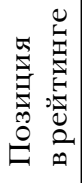 & Компания & $\begin{array}{c}\text { Сектора } \\
\text { әкономики }\end{array}$ & 焉 & Компания & $\begin{array}{c}\text { Сектора } \\
\text { экономики }\end{array}$ \\
\hline 1 & Apple Inc. & $\begin{array}{l}\text { Электроника, } \\
\text { информационные } \\
\text { технологии }\end{array}$ & 6 & $\begin{array}{l}\text { Berkshire } \\
\text { Hathaway }\end{array}$ & $\begin{array}{l}\text { Страхование, финансы, } \\
\text { железнодорожный транс- } \\
\text { порт, коммунальные услуги, } \\
\text { производство продуктов } \\
\text { питания, обрабатывающая } \\
\text { промышленность }\end{array}$ \\
\hline 2 & $\begin{array}{l}\text { Alphabet } \\
\text { Inc. }\end{array}$ & Интернет & 7 & Alibaba & $\begin{array}{l}\text { Электронная торговая плат- } \\
\text { форма - форма типа В2С }\end{array}$ \\
\hline 3 & Microsoft & $\begin{array}{l}\text { Программное обеспе- } \\
\text { чение и компьютер- } \\
\text { ные услуги }\end{array}$ & 8 & Facebook & Интернет \\
\hline 4 & $\begin{array}{l}\text { Amazon } \\
\text { Inc. }\end{array}$ & $\begin{array}{l}\text { Электронная тор- } \\
\text { говая платформа - } \\
\text { форма типа В2С }\end{array}$ & 9 & $\begin{array}{l}\text { JP Morgan } \\
\text { Chase }\end{array}$ & Банки \\
\hline 5 & $\begin{array}{l}\text { Tencent } \\
\text { Holdings }\end{array}$ & $\begin{array}{l}\text { Интернет-услуги, } \\
\text { искусственный } \\
\text { интеллект, электрон- } \\
\text { ные развлечения, } \\
\text { венчурный капитал }\end{array}$ & 10 & $\begin{array}{l}\text { Johnson \& } \\
\text { Johnson }\end{array}$ & $\begin{array}{l}\text { Фармацевтика } \\
\text { и биотехнология }\end{array}$ \\
\hline
\end{tabular}

Примечание. В таблице выделены фирмы, относящиеся к цифровой экономике, остальные - к промышленным и инфраструктурным традиционным секторам (энергетика, транспорт, промышленность).

Источник: таблица составлена по данным www.pwc.com, https:/ / www.ft.com

Таблица 3

Рейтинг российских крупнейших компаний по капитализации, 2018 г.

\begin{tabular}{|c|c|c|c|c|c|}
\hline 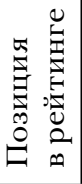 & Компания & $\begin{array}{c}\text { Сектора } \\
\text { экономики }\end{array}$ & ص & Компания & $\begin{array}{c}\text { Сектора } \\
\text { экономики }\end{array}$ \\
\hline \multicolumn{6}{|c|}{ Несырьевые экспортеры } \\
\hline 1 & $\begin{array}{l}\text { Рособорон- } \\
\text { экспорт }\end{array}$ & Машиностроение & 6 & Нокиан шина & $\begin{array}{l}\text { Химическая } \\
\text { и нефтехимическая } \\
\text { промышленность }\end{array}$ \\
\hline 2 & Росатом & $\begin{array}{l}\text { Многоотраслевой } \\
\text { холдинг }\end{array}$ & 7 & $\begin{array}{l}\text { Объединенная } \\
\text { авиастроитель- } \\
\text { ная корпорация }\end{array}$ & Машиностроение \\
\hline 3 & $\begin{array}{l}\text { Объединенная } \\
\text { двигателе- } \\
\text { строительная } \\
\text { корпорация }\end{array}$ & Машиностроение & 8 & ИРЭ-Полюс & Машиностроение \\
\hline 4 & $\begin{array}{l}\text { Тактическое } \\
\text { ракетное } \\
\text { вооружение }\end{array}$ & Машиностроение & 9 & $\begin{array}{l}\text { Объединенная } \\
\text { ракетно-кос- } \\
\text { мическая } \\
\text { корпорация }\end{array}$ & Машиностроение \\
\hline
\end{tabular}


Окончание таблицы 3

\begin{tabular}{|c|c|c|c|c|c|}
\hline 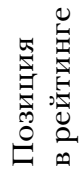 & Компания & $\begin{array}{c}\text { Сектора } \\
\text { экономики }\end{array}$ & ص & Компания & $\begin{array}{c}\text { Сектора } \\
\text { экономики }\end{array}$ \\
\hline 5 & ВСМПО-Ависма & $\begin{array}{l}\text { Цветная } \\
\text { металлургия }\end{array}$ & 10 & Ренова & $\begin{array}{l}\text { Многоотраслевой } \\
\text { холдинг }\end{array}$ \\
\hline \multicolumn{6}{|c|}{ Все экспортеры } \\
\hline 1 & Роснефть & $\begin{array}{l}\text { Нефтяная } \\
\text { и нефтегазовая } \\
\text { промышленность }\end{array}$ & 6 & Татнефть & $\begin{array}{l}\text { Нефтяная } \\
\text { и нефтегазовая } \\
\text { промышленность }\end{array}$ \\
\hline 2 & Газпром & $\begin{array}{l}\text { Нефтяная } \\
\text { и нефтегазовая } \\
\text { промышленность }\end{array}$ & 7 & РУСАЛ & $\begin{array}{l}\text { Нефтяная } \\
\text { и нефтегазовая } \\
\text { промышленность }\end{array}$ \\
\hline 3 & ЛУКойл & $\begin{array}{l}\text { Нефтяная } \\
\text { и нефтегазовая } \\
\text { промышленность }\end{array}$ & 8 & $\begin{array}{l}\text { Сахалин } \\
\text { энерджи }\end{array}$ & $\begin{array}{l}\text { Нефтяная } \\
\text { и нефтегазовая } \\
\text { промышленность }\end{array}$ \\
\hline 4 & Сургутнефтегаз & $\begin{array}{l}\text { Нефтяная } \\
\text { и нефтегазовая } \\
\text { промышленность }\end{array}$ & 9 & $\begin{array}{l}\text { Новолипецкий } \\
\text { металлургиче- } \\
\text { ский комбинат }\end{array}$ & Черная металлургия \\
\hline 5 & Норникель & $\begin{array}{l}\text { Цветная } \\
\text { металлургия }\end{array}$ & 10 & СУЭК & $\begin{array}{l}\text { Угольная } \\
\text { промышленность }\end{array}$ \\
\hline
\end{tabular}

Примечание. Все компании в таблице относятся к промышленным и инфраструктурным традиционным секторам (энергетика, транспорт, промышленность).

Источник: АЦ «Эксперт» (Специальный доклад..., 2019, с. 68).

\section{ЛИТЕРАТУРА / REFERENCES}

Глазатов М.В. (2017). Практика субсидирования: некоторые аспекты разрешения споров в ВТО // Торговая политика (Trade policy). № 1 (9). С. 75-101. Режим доступа: https://tpjournal.hse.ru/article/view/8323. [Glazatov M.V. (2017). Subsidy practice: Some aspects of dispute resolution in the WTO. Trade Policy, 1 (9), 75-101. Available at: https://tpjournal. hse.ru/article/view/8323 (in Russian).]

Симачев Ю.В., Акиндинова Н.В., Яковлев А.А., Миронов В.В., Данильцев А.В., Глазатова М.К., Бессонов В.А., Вишневский К.О., Кузык М.Г., Куценко Е.С., Медовников Д.С., Розмирович С.Д. (2018). Структурная политика в России: новые условия и возможная повестка: доклад к XIX Апрельской международной научной конференции по проблемам развития экономики и общества. Москва, 10-13 апреля 2018 г. Е.Г. Ясин (науч. ред.). М.: Издательский дом НИУ ВШЭ. [Simachev Y.V., Akindinova N.V., Yakovlev A.A., Mironov V.V., Daniltsev A.V., Glazatova M.K., Bessonov V.A., Vishnevsky K.O., Kuzyk M.G., Kutsenko E.S., Medovnikov D.S., Rozmirovich S.D. (2018). Structural policy in Russia: New conditions and possible agenda: report to the XIX April international scientific conference on economic and social development. Moscow, April 10-13, 2018. E.G. Yasin (ed.). Moscow: HSE Publishing House (in Russian).]

Специальный доклад «Рейтинг крупнейших экспортеров России» (2019) // Эксnерт. № 39. 23-29 сентября. С. 68 [Special report "Rating of Russia's largest exporters" (2019). Expert, 39, September 23-29, 68 (in Russian).]

Bhagwati J.N. (1995). US trade policy: The infatuation with FTAs. Discussion Paper Series No. 726. American Economic Association meetings. January. 
Constantinescu C., Mattoo A., Ruta M. (2019). Policy uncertainty, trade, and global value chains: Some facts, many questions policy research. Working Paper 9048. October, 9.

Matoo A., Staiger R. W. (2019). Trade Wars What Do They Mean? Why Are They Happening Now? What Are the Costs? Policy Research Working Paper 8829. April 2019.

PWC (2017). The long view how will the global economic order change by 2050? Available at: https://www.pwc.com/gx/en/world2050 / assets / pwc-the-world-in-2050-fullreport-feb-2017.pdf

Schwab K. (2016). The Fourth industrial revolution. World Economic Forum, 12. Available at: https://www.pdfdrive.com/the-fourthindustrial-revolution-e39623145.html

World Bank Group (2018). Global Trade Watch Trade. Amid Tensions. Wash. DC, 18.

Поступила в редакиию 18.02.2020

Received 18.02.2020

\title{
M.K. Glazatova
}

National Research University Higher School of Economics, Moscow, Russia

\section{A.V. Daniltsev}

National Research University Higher School of Economics, Moscow, Russia

\section{Main trends in the development of world trade and structural features of Russian exports}

\begin{abstract}
Global trends and structural shifts in the development of international trade, which have a fundamental character, and will continue to develop for more than a decade, are considered. It is noted that significant changes were particularly impressive in the communication sphere, which, in turn, affected the most socially sensitive sector of the economy - services. The article analyzes the causes of crisis phenomena in the multilateral system of trade regulation based on liberalization and harmonization of rules for traditional forms of trade, as well as the growth of protectionism in the conditions of the formation of trade continents - modern forms of regional agreements. The article deals with the influence of regionalism scaling on the narrowing of the free market space and the aggravation of problems of interaction between economic agents. The risks associated with the slowdown in world trade and the application of trade restrictions, as well as problems in the regulation of global trade, are considered. Special attention is paid to the dynamics of changes in the structure of Russian exports; and there is a clear discrepancy between the structures of Russian exports to global demand. It is assumed that this effect can be explained by increased competition in the world market, slowly recovering from the crisis, deepening stagnation of the domestic output, widening technological gap, as well as accumulated internal problems that have reduced the dynamism and capabilities of the Russian economy. Attention is drawn to the fact that among the TOP 10 non-raw material Russian exporters, there are no enterprises which activities are related to digital technologies, in contrast to the results of world rankings that put technology companies in the foreground.
\end{abstract}

Keywords: international trade, protectionism, multilateral trade regulation, export, services,

JEL Classification: F10, F13.

DOI: $10.31737 / 2221-2264-2020-45-1-8$ 